\title{
RANCANG BANGUN MESIN PENGISIAN CURAH TEMBAKAU KE DALAM BIN
}

\author{
Wahyu Wiriaatmadja \\ Fakultas Teknik, Program Studi Teknik Mesin \\ Universitas Muria Kudus \\ Email : atmadja997@gmail.com \\ Masruki Kabib \\ Fakultas Teknik, Program Studi Teknik Mesin \\ Universitas Muria Kudus \\ Email : masruki.kabib@umk.ac.id \\ Taufiq Hidayat \\ Fakultas Teknik, Program Studi Teknik Mesin \\ Universitas Muria Kudus \\ Email : taufiq.hidayat@umk.ac.id
}

\begin{abstract}
ABSTRAK
Mesin pengisian curah tembakau merupakan suatu alat yang di gunakan untuk mengisikan curah tembakau dari conveyor ke dalam bin wadah curah tembakau yang telah ditentukan. Mesin pengisian curah tembakau berfungsi untuk mengisikan dan meratakan curah tembakau kedalam bin dengan massa tembakau $10 \mathrm{Kg}$. Perancangan sistem pengisia curah tembakau bertujuan untuk merancang dan membuat mesin pengisian curah tembakau ke dalam bin. Metode perancangan mesin pengisian curah tembakau dimulai dari sketsa gambar, mendesain mesin, perancangan dan perhitungan, pembuatan gambar kerja, proses pembuatan sistem pengisian curah tembakau dan pembuatan mesin pengisian curah tembakau. Hasil penelitian adalah telah dirancangan dan dibuat mesin pengisian curah tembakau dengan menggunakan motor listrik 74 Watt untuk menggerakkan hopper. dengan torsi 32 N.m, dan kecepatan putar 10 rpm. Sistem buka dan menutup hopper- mesin pengisian curah tembakau digerakkan menggunakan 2 motor servo spesifikasi torsi 1000 N.mm dan kecepatan putar 24 rpm
\end{abstract}

Kata kunci : bin, curah tembakau, penutup hopper, motor listrik.

\section{ABSTRACT}

Tobacco bulk filling machine is a tool that is used to fill the tobacco from the conveyor into the bin of the tobacco container that has been determined. Tobacco filling machine functions to fill and level the of tobacco into a bin with a tobacco mass of $10 \mathrm{~kg}$. The design of the tobacco filling system aims to design and create a tobacco filling machine to the bin. The method of designing a tobacco filling machine starts from drawing sketches, designing machines, designing and calculating, making working drawings, the process of making a tobacco filling system and making a tobacco filling machine. The results of the study were designed and made for a tobacco filling machine using a 74 Watt electric motor to drive the hopper. with 32 N.m of torque, and a rotational speed of $10 \mathrm{rpm}$. Open and close hopper system-tobacco filling machine is driven using 2 servo motors with a torque specification of $1000 \mathrm{~N} . \mathrm{mm}$ and a rotational speed of $24 \mathrm{rpm}$

Key word: bin, tobacco bulk, connecting rod, hopper cover, electric motor. 


\section{PENDAHULUAN}

Manufaktur merupakan suatu proses pekerjaan permesinan yang mengubah bahan masih mentah menjadi barang jadi untuk di jual, kegiatan ini dilakukan oleh banyak manusia yang berupa kerajinan tangan sampai produksinya menggunakan alat - alat berteknologi tinggi dan canggih, di era yang serba canggih ini di bidang manufaktur permesinan sangat berkembang pesat dimana alat - alat tersebut digunakan untuk mempermudah dan mempercepat pekerjaan dan produktifitas yang sedang dilakukan, jadi hasil yang diperoleh akan memuaskan pelanggan dan meningkatkan produktifitas mereka pula [1]. Industri kecil menengah dan bengkel sederhana, mesih menggunakan peralatan mesin yang terbatas penggunaanya, misalnya pada proses packing masih dibantu mengggunakan tenaga manusia dalam pengisiannya. Proses pengepresan dan pemotongan bahan plastik untuk proses packing telah di kembangkan dengan sistem pneumatik [2]. Perkembangan teknologi semakin hari semakin modern, sehingga menjadi tantangan menghadapi dunia kerja. Perancangan dan pengembangan produk yang tepat, dapat menciptakan peralatan yang baik dan maksimal dalam penggunaan di industri [3].

Industri saat ini dalam proses produksinya menggunakan alat - alat berteknologi tinggi dan canggih, di era yang serba canggih ini di industri pemesinan juga sangat berkembang pesat dimana alat - alat tersebut digunakan untuk mempermudah dan mempercepat pekerjaan dan meningkatkan produktifitas. Industri rokok juga menggunakan mesin yang berteknologi tinggi. Sistem otomasi di industri digunakan dengan sangat efektif untuk meningkatkan produktifitas. Proses pemisahan daun tembakau dengan tulangnya, pemindahan satu mesin ke mesin berikutnya, pemasakan bahan baku rokok, perajangan tembakau, dan pemisahan rajangan ukuran tembakau sudah secara otomasi. Industri rokok dalam proses pemasukan rajangan tembakau (curah tembakau) kedalam cetakan bin/wadah curah tembakau untuk dipindah ke mesin SKM (Sigaret Kretek Mesin) masih mengunakan bantuan manusia. Proses pemasukkan akan banyak menghabiskan waktu dengan hasil kurang maksimal Disisi lain perkembangan mutu pembelajaran di perguruan tinggi semakin hari semakin modern untuk proses menghadapi dunia kerja. Proses dengan perancangan serta pengembangan produk yang tepat, dapat menciptakan peralatan yang baik dan maksimal dalam penggunaan [4].

Mesin pengisian curah tembakau merupakan suatu alat atau perkakas yang di gunakan untuk mengisikan curah tembakau dari conveyor yang terdapat chute hopper kedalam bin/cetakan wadah curah tembakau yang telah ditentukan[5]. Untuk memperoleh hasil penggisian curah yang baik dan sesuai dengan yang diinginkan, maka ukuran mulut bin dan ukuran chute hopper harus sesuai dengan kemampuan dari curah untuk mampu melewati hopper tanpa terhambat dan kecepatan motor untuk menggerakkan hopper. Kemampuan curah tembakau untuk mampu melewati hopper dipengaruhi dari sudut kemiringan sudut mulut masuk hopper dan ukuran luasan hopper. Pengontrol sistem putaran motor bisa dilakukan secara manual maupun otomatis tergantung pada spesifikasi motor pada mesin. Ada beberapa bagian-bagian utama dari suatu sistem mesin penyusun curah yaitu motor yang dipasang connecting rod dan terhubung ke hopper yang diberi roda yang berfungsi sebagai penggerak maju mundur hopper, rel roda yang berfungsi sebagai jalur gerakan roda hopper [6].

Proses pengisian curah tembakau ke dalam bin saat ini masih manual. Proses pengisian curah tembakau terdapat 3 proses yaitu proses pengisian, proses pemindahan dan proses penimbangan. Proses pengisian masih menggunakan tenaga manusia. Curah tembakau yang jatuh dari chute ke dalam bin akan bebentuk menggunung dan diratakan oleh manusia. Proses pemindahan bin menggunakan roll glinding. Bin ditaruh dibawah chute hopper conveyor diatas roll gelinding. Proses penimbangan masih secara manual juga sehingga saat kurang maka ditambahi oleh operatornya. Kemudian bin ditumpuk sehingga proses tersebut memerlukan waktu yang cukup lama [7].

Mesin pengisian curah tembakau menggunakan sistem pengarah jatuhan tembakau kedalam bin secara merata. Mesin pengisian curah tembakau tidak boleh menggunakan system vibrasi untuk meratakannya karena jika di vibrasi tembakau yang sudah di campur sebelumnya akan mengalami pemisahan kembai antara cengkeh dan rajangan tembakaunya. Sistem pengisian curah tembakau menggunakan sistem hopper bergerak untuk mengarahkan rajangan tembakaunya dan penentuan massanya menggunakan load cell. Berdasakan hal-hal tersebut perlu diciptakan suatu mesin dengan sistem pengisian curah tembakau secara otomatis dalam pengisian dan perataan curah tembakau ke dalam bin [8].

Tujuan penelitian ini adalah merancang dan membuat sitem pengisian curah tembakau ke dalam bin secara merata dengan massa tembakau $10 \mathrm{~kg}$.

\section{METODOLOGI PENELITIAN}

Metode penelitian ini adalah perancangan dan pembuatan sistem pengisian curah tembakau, dengan langkah langkah sebagaimana di tunjukkan pada gambar 1. 


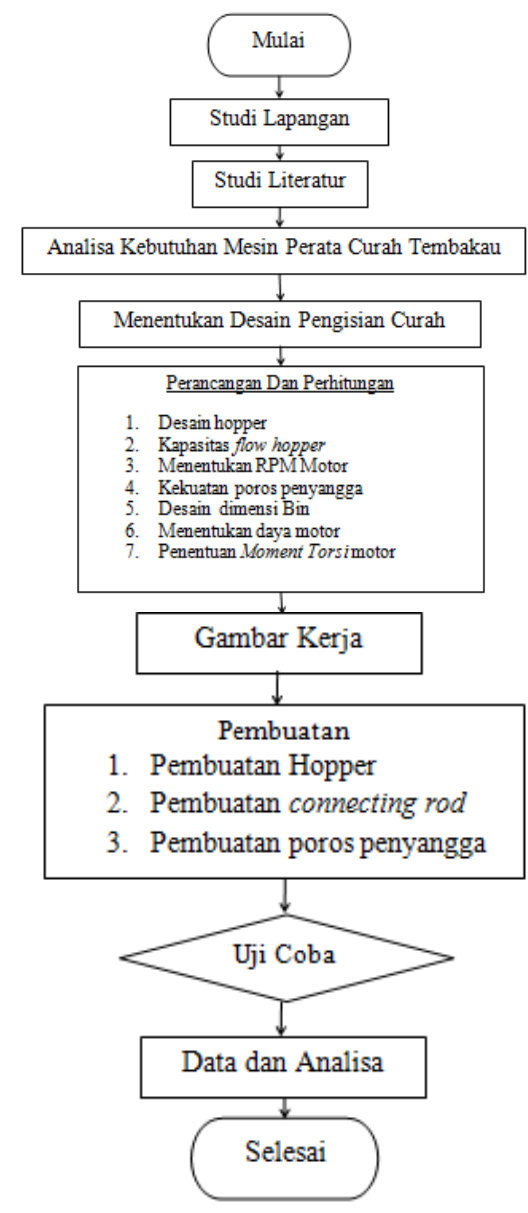

Gambar 1. Diagram alir perancangan sistem pengisian curah tembakau

Metode perancangan dan pembuatan sistem pengisian curah tembakau dimulai dari studi literatur, analisa kebutuhan mesin pada proses industri, pembuatan konsep sistem pengisian curah tembakau ke dalam bin (wadah) dan membuat desain system pengisian curah tembakau, Mulai perancangan alat, melakukan perancangan kerangka dan perancangan komponen lain sebelum dilakukan perhitungan, perhitungan muatan pada hopper per detik, perhitungan torsi penggerak, connecting rod, perhitungan penyangga dan putaran motor hopper, membuat gambar kerja pengerjaan tiap komponen melakukan pembuatan hopper, connecting rod, penyangga dan pemilihan motor, uji coba hasil perancangan dengan perhitungan.

\section{HASIL DAN PEMBAHASAN}

\subsection{Analisa kebutuhan}

Dalam merancang sistem pengisian curah tembakau ini analisa kebutuhan yang dibutuhkan meliputi:

1. Aspek Desain

Aspek desain pengisian meliputi mampu untuk merakan curah tembakau ke dalam bin, proses pembuatan sistem pengisian curah tembakau dan komponen yang digunakan relatif mudah didapat dan murah dalam perawatan.

2. Aspek manufaktur

Kontruksi perancangan sistem pengisian tembakau meliputi perancangan mekanisme gerak hopper sesuai dengan kapasitas conveyor sebelumnya $0.8 \mathrm{Kg} / \mathrm{s}$. Pembuatan komponen meliputi roda, connecting rod panjang dan pendek, motor listrik, hopper, penutup hopper, dan motor servo.

3. Aspek Teknik

Aspek teknik meliputi tentang cara kerja komponen yaitu, motor wiper sebagai penggerak utama menggerakkan hopper dengan penghubung gerakan dari motor ke hopper menggunakan connecting rod pendek dan dilanjutkan ke connecting rod panjang yang terhubung dengan hopper, sehingga terjadi gerakan bolak balik secara horizontal.

4. Aspek Ergonomi

Keselamatan kerja sangat penting dalam melakukan pekerjaan dengan pemilihan jenis material sistem pengisian curah tembakau yang digunakan bersifat aman tidak membahayakan dan kuat, perancangan tiap 
komponen dapat dilepas sehingga memudahkan dalam proses perawatan penggantian component. Tinggi hopper sesuai tinggi siku manusia.

\subsection{Desain mesin pengisian curah tembakau}

Perancangan mesin pengisian curah tembakau merupakan kemampuan mesin pengisian curah tembakau untuk mengisi curah tembakau kedalam bin secara merata. Komponen-komponen mesin pengisian curah tembakau meliputi motor penggerak, Hopper, connecting rod panjang dan pendek, poros penyangga dan roda.

Mesin pengisian curah tembakau dalam perancangannya dimulai dari : Perancangan kapasitas hopper, perancangan kekuatan penutup hopper, perancangan ukuran bin, perancangan connecting rod pendek, perancangan connecting rod panjang, perancangan penggunaan motor. Desain mesin pengisian curah tembakau dapat dilihat pada gambar 2 .

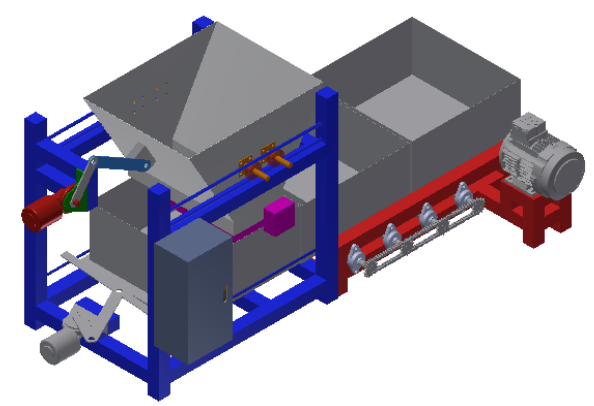

Gambar 2. Mesin pengisian curah tembakau

\subsection{Perhitungan Mesin Perata Curah Tembakau}

Perhitungan mesin perata curah tembakau ini adalah suatu usaha untuk mengarahkan jatuhan curah tembakau kedalam bin secara merata dimana kapasitas jatuhan dari proses sebelumnya $0.8 \mathrm{Kg} / \mathrm{s}$. Ada beberapa langkah perhitungan untuk menentukan pengisian curah tembakau yaitu mencari putaran motor, torsi motor, dalam pengisian curah tembakau kedalam bin dengan massa $10 \mathrm{~kg}$.

\subsubsection{Hopper}

Perancangan hopper menggunakan bahan seng. Untuk rumus yang digunakan penentuan sudut kemiringan mulut hopper $60^{\circ}$. Untuk menentukan koefisien gesek pada permukaan hopper. Dihitung dengan rumus persamaan 1:

$$
\mu=\tan \theta
$$

Dimana $\mu$ adalah koefisien gesek, $\Theta$ adalah sudut kemiringan permukaan hopper $\left(^{\circ}\right)$

Analisa koefisien gesek hopper dihasilkan nilai sebagaimana ditunjukkan pada tabel 1.

Tabel 1 analisa koefisien gesek hopper

\begin{tabular}{lcc}
\hline \multicolumn{1}{c}{ Analisa } & Hasil & Satuan \\
\hline koefisien gesek & 1.73 & - \\
kemiringan sudut & 60 & derajat \\
\hline
\end{tabular}

\subsubsection{Kapasitas aliran curah tembakau}

Kapasitas aliran curah tembakau merupakan banyaknya tembakau yang mengalir melewati hopper dari conveyor dan mengisi ke dalam bin. Massa tembakau $20 \mathrm{Kg}$ dalam waktu pengisian $25 \mathrm{~s}$. Dihitung dengan menggunakan rumus persamaan 2 :

$$
\mathrm{Q}=\frac{\mathrm{m}}{\mathrm{t}}
$$

Dimana Q adalah kapasitas pengisian curah tembakau sampai penuh $(\mathrm{Kg} / \mathrm{s})$, m adalah Massa penuh 1 bin $(\mathrm{Kg}), \mathrm{t}$ adalah waktu pengisian curah sampai penuh (s)

Analisa kapasitas aliran curah tembakau dihasilkan nilai sebagaimana ditunjukkan pada tabel 2. 


\begin{tabular}{|c|c|c|}
\hline Analisa & Hasil & Satuan \\
\hline Massa tembakau (25 s) & 20 & $\mathrm{Kg}$ \\
\hline Waktu & 25 & detik \\
\hline Kapasitas conveyor & 0.8 & $\mathrm{Kg} / \mathrm{s}$ \\
\hline
\end{tabular}

\subsubsection{Perhitungan Moment Torsi Motor}

Momen torsi motor penggerak hopper dipengaruhi oleh berat hopper, connecting rod panjang dan pendek, curah tembakau didalam hopper, kerangka hopper, roda. Perhitungan Moment torsi menggunakan rumus persamaan 3 :

$$
\tau=F_{\text {total }} \cdot r \cos \theta
$$

Dimana r adalah panjang conecting rod pendek (m)

Analisa momen torsi yang dibutuhkan dihasilkan nilai sebagaimana ditunjukkan pada tabel 3 .

Tabel 3 Analisa momen torsi yang dibutuhkan

\begin{tabular}{lcl}
\hline \multicolumn{1}{c}{ Analisa } & Hasil & Satuan \\
\hline Berat total connecting rod & 21 & $\mathrm{~N}$ \\
Berat tembakau di hopper & 24 & $\mathrm{~N}$ \\
Gaya pada roda & 31.32 & $\mathrm{~N}$ \\
Gaya kelembaman & 52,289 & $\mathrm{~N}$ \\
Sudut penggayaan $(\Theta)$ & 0,1 & $\mathrm{~N}$ \\
Jarak pembebanan & 416,5 & $\mathrm{~mm}$ \\
Moment torsi & 52,98 & N.m \\
\hline
\end{tabular}

\subsubsection{Perhitungan putaran motor listrik}

Perancangan motor menggunakan motor listrik 1 fasa. Waktu jatuh $180^{\circ}$ dibutuhkan waktu $3 \mathrm{~s}$. sehingga 1 putaran dibutuhan waktu $6 \mathrm{~s}$, maka putaran dapat dirumuskan dengan persamaan 4:

$$
\mathrm{n}=\frac{\omega}{\mathrm{t}}
$$

Dimana $\omega$ adalah jumlah rotasi, $\mathrm{n}$ adalah rotasi per menit (rpm), dan $\mathrm{t}$ adalah waktu (s)

Analisa putaran motor listrik pernggerak hopper dihasilkan nilai sebagaimana ditunjukkan pada tabel 4.

Tabel 4 analisa putaran motor listrik penggerak hopper

\begin{tabular}{ccc}
\hline Analisa & Hasil & Satuan \\
\hline Waktu (6s) & 10 & $\mathrm{rpm}$ \\
\hline
\end{tabular}

\subsubsection{Perhitungan Daya Motor}

Perancangan daya motor pengisian curah tembakau untuk menggerakkan hopper memerlukan momen torsi sebesar 52,98 N.m.Menggunakan rumus persamaan 5 :

$$
\mathrm{MT}=9550 \times \frac{\mathrm{P}}{\mathrm{n}}
$$

Dimana MT adalah Moment torsi motor (N.m), P adalah Daya motor (KW), $\mathrm{n}$ adalah kecepatan putar motor (rpm)

Analisa daya motor penggerak hopper dihasilkan nilai sebagaimana ditunjukkan pada tabel 5.

Tabel 5 analisa daya motor penggerak hopper

\begin{tabular}{lcc}
\hline \multicolumn{1}{c}{ Analisa } & Hasil & Satuan \\
\hline Momen torsi & 52,98 & N.m \\
Putaran motor & 10 & rpm \\
Daya motor hopper & 74 & watt \\
\hline
\end{tabular}

\subsection{Proses pembuatan}

Proses pembuatan mesin pengisian curah tembakau dimulai dari pengeboran hopper, connecting rod panjang dan pendek, pemotongan penutup hopper dan pengelasan kerangka hopper. Perakitan mesin pengisian 
curah tembakau diawali dengan pemasangan motor listrik penggerak hopper kemudian dipasang connecting rod panjang dan pendek dihubungkan dengan hopper yang sudah dirakit dengan roda kerangka dan penutupnya.

\subsubsection{Pengeboran hopper system Pengisian Curah Tembakau}

Proses pengeboran pada hopper sistem pengisian curah tembakau. Pengeboran dimulai dengan mata bor kecil $2 \mathrm{~mm}$ untuk liner awal dan dilanjutkan mata bor $3 \mathrm{~mm}$ dengan kecepatan sayat $19 \mathrm{~m} / \mathrm{s}$. perhitungan perumusan kecepatan pengeboran menggunakan rumus persamaan 6 :

$$
\mathrm{N}=\frac{\mathrm{v} \times 1000}{\pi \times \mathrm{d}}
$$

Dimana $\mathrm{v}$ adalah kecepatan potong $(\mathrm{m} / \mathrm{s})$, d adalah diameter mata bor Analisa pengeboran hopper sistem pengisian curah tembakau dihasilkan nilai sebagaimana ditunjukkan pada tabel 6 .

Tabel 6 analisa pengeboran hopper system Pengisian Curah Tembakau

\begin{tabular}{lcl}
\hline \multicolumn{1}{c}{ Analisa } & Hasil & Satuan \\
\hline Kecepatan sayat & 19 & $\mathrm{~mm} / \mathrm{menit}$ \\
Diameter awal & 2 & $\mathrm{~mm}$ \\
Diameter akhir & 3 & $\mathrm{~mm}$ \\
Putaran motor & 2016,98 & $\mathrm{rpm}$ \\
\hline
\end{tabular}

Analisa pengeboran conecting rod panjang dan pendek dihasilkan nilai sebagaimana ditunjukkan pada tabel 7 .

Tabel 7 analisa pengeboran conecting rod panjang dan pendek system Pengisian Curah Tembakau

\begin{tabular}{lcl}
\hline \multicolumn{1}{c}{ Analisa } & Hasil & Satuan \\
\hline Kecepatan sayat & 19 & $\mathrm{~mm} /$ menit \\
Diameter awal & 6 & $\mathrm{~mm}$ \\
Diameter akhir & 6 & $\mathrm{~mm}$ \\
Putaran motor & 504,245 & $\mathrm{rpm}$ \\
\hline
\end{tabular}

Panjang $1_{\mathrm{w}}$ adalah $3 \mathrm{~mm}$ sesuai diameter mata bor pada hopper dan $6 \mathrm{~mm}$ pada connecting rod Panjang pengeboran menggunakan perhitungan pada persamaan 7 :

$$
l_{v}=\operatorname{tangen} 30^{\circ} \cdot 1 / 2 \mathrm{~d}
$$

Dimana lv adalah panjang awalan (mm)

Analisa panjang pengeboran hopper dihasilkan nilai sebagaimana ditunjukkan pada tabel 8.

Tabel 8 analisa panjang pengeboran hopper

\begin{tabular}{ccc}
\hline \multicolumn{1}{c}{ Analisa } & Hasil & Satuan \\
\hline Panjang $l_{\mathrm{v}}$ & 0.26 & $\mathrm{~mm}$ \\
Panjang $l_{\mathrm{n}}$ & 0.85 & $\mathrm{~mm}$ \\
\hline
\end{tabular}

Analisa panjang pengeboran connecting rod panjang dan pendek dihasilkan nilai sebagaimana ditunjukkan pada tabel 9.

Tabel 9 analisa panjang pengeboran connecting rod panjang dan pendek

\begin{tabular}{lcc}
\hline \multicolumn{1}{c}{ Analisa } & Hasil & Satuan \\
\hline Panjang awalan & 3.42 & $\mathrm{~mm}$ \\
Panjang pengakhiran & 3,42 & $\mathrm{~mm}$ \\
\hline
\end{tabular}

Waktu pengeboran sistem pengisian curah tembakau terdiri dari hopper dan connecting rod panjang dan pendek.. perhitungan menggunakan persamaan 8 :

$$
t_{c}=\frac{l_{t}}{v_{f}}
$$

Dimana $t_{c}$ adalah waktu pemotongan $(\mathrm{s}), \mathrm{V}$ kecepatan penyayatan $(\mathrm{m} / \mathrm{s})$, dan $\mathrm{l}_{\mathrm{t}}$ adalah panjang total pengeboran

Analisa waktu pengeboran hopper dihasilkan nilai sebagaimana ditunjukkan pada tabel 10 . 
Tabel 10 analisa waktu pengeboran hopper

\begin{tabular}{lcl}
\hline \multicolumn{1}{c}{ Analisa } & Hasil & Satuan \\
\hline Panjang total & 4,11 & $\mathrm{~mm}$ \\
Kecepatan penyayatan & 19 & $\mathrm{~mm} /$ menit \\
Waktu pengeboran & 0,216 & menit \\
\hline
\end{tabular}

Analisa waktu pengeboran connecting rod panjang dan pendek dihasilkan nilai sebagaimana ditunjukkan pada tabel 11.

Tabel 11 analisa waktu pengeboran connecting rod panjang dan pendek

\begin{tabular}{lcl}
\hline \multicolumn{1}{c}{ Analisa } & Hasil & Satuan \\
\hline Panjang total & 58,482 & $\mathrm{~mm}$ \\
Kecepatan penyayatan & 19 & $\mathrm{~mm} /$ detik \\
Waktu pengeboran & 3,045 & menit \\
\hline
\end{tabular}

\subsubsection{Proses pengelasan kerangka hopper}

Proses pengelasan kerangka hopper. Pengelasan yang dilakukan pada kerangka hopper dengan dimensi luasan kerangka $10 \mathrm{~mm}$ dan banyaknya titik pengelasan adalah 15. Perhitungan waktu pengelasan menggunakan persamaan 9 :

$$
\text { Waktu }(t)=\frac{\text { panjang total pengelasan }(\mathrm{mm})}{\text { waktu pengelasan }(\mathrm{mm})}
$$

Analisa waktu proses pengelasan kerangka hopper dihasilkan nilai sebagaimana ditunjukkan pada tabel 12.

Tabel 12 analisa waktu proses pengelasan kerangka hopper

\begin{tabular}{lcl}
\hline \multicolumn{1}{c}{ Analisa } & Hasil & Satuan \\
\hline Waktu pengelasan & 10 & $\mathrm{~mm} /$ menit \\
Panjang total pengelasan & 150 & $\mathrm{~mm} /$ detik \\
Waktu yang dibutuhkan & 15 & menit \\
\hline
\end{tabular}

Perhitungan waktu pengelasan menggunakan persamaan 10 :

$$
\text { Jumlah elektroda }=\frac{\text { luas lasan }\left(\mathrm{mm}^{2}\right)}{\text { total panjang }(\mathrm{mm})} .1 \text { batang }
$$

Analisa jumlah elektroda yang dibutuhkan pengelasan kerangka hopper dihasilkan nilai sebagaimana ditunjukkan pada tabel 13 .

Tabel 13 analisa waktu jumlah elektroda yang dibutuhkan untuk pengelasan kerangka hopper

\begin{tabular}{lcc}
\hline \multicolumn{1}{c}{ Analisa } & Hasil & Satuan \\
\hline Luasan lasan & 100 & $\mathrm{~mm}^{2}$ \\
Elektroda yang dibutuhkan & 1.5 & batang \\
\hline
\end{tabular}

\section{Hasil Implementasi}

Data percobaan pengujian kecepatan jatuhan curah tembakau kedalam bin dihasilkan nilai sebagaimana ditunjukan pada tabel 14:

Tabel 14. Hasil Pengujian kecepatan jauh pengisian curah tembakau

\begin{tabular}{ccc}
\hline Nilai Standart (s) & Nilai Uji (s) & Satuan \\
\hline 1 & 1,3 & $\mathrm{~s}$ \\
1 & 1,1 & $\mathrm{~s}$ \\
1 & 1,1 & $\mathrm{~s}$ \\
1 & 1,2 & $\mathrm{~s}$ \\
1 & 1,4 & $\mathrm{~s}$ \\
\hline Rata-rata & 1,22 & $\mathrm{~s}$ \\
\hline
\end{tabular}

Perhitungan efisiensi pengisian curah tembakau menggunakan rumus persamaan 11 :

$$
\text { efisiensi }=\frac{\text { nilai standart }}{\text { nilai rata-rata pengujian }} \times 100 \%
$$

Analisa efisiensi pengisian curah tembakau dihasilkan nilai sebagaimana ditunjukkan pada tabel 15 . 
Tabel 15 analisa efisiensi pengisian curah tembakau

\begin{tabular}{ccc}
\hline Analisa & Hasil & Satuan \\
\hline efisiensi & 81,9 & persen \\
\hline
\end{tabular}

Proses pengisian curah tembakau memiliki efisiensi pengisian yang cukup baik yaitu $81,9 \%$.

\section{KESIMPULAN}

Penelitian ini menghasilkan rancangan dan pembuatan mesin pengisian curah tembakau ke dalam bin dengan massa $10 \mathrm{~kg}$, dengan kapasitas laju aliran curah konveyor $0,8 \mathrm{Kg} / \mathrm{s}$ memiliki efisiensi jatuhan sebesar $81,9 \%$ dari waktu yang ditentukan $1 \mathrm{~s}$. Motor utama penggerak hopper memiliki spesifikasi daya 74 watt, momen torsi 52,98 N.m, dan putaran motor $10 \mathrm{rpm}$.

\section{DAFTAR PUSTAKA}

[1] P. Kushartanto, M. Kabib, R. Winarso, 2019, "Sistem Kontrol Gerak Dan Perhitungan Produk Pada Mesin Pres Dan Pemotong Kantong Plastik," Jurnal Crankshaft, vol. 2, no. 1, pp. 57-66.

[2] R.F. Indriyanto, M. Kabib, R. Winarso, 2018, "Rancang Bangun Sistem Pengepresan Dengan Penggerak Pneumatik Pada Mesin Press Dan Potong Untuk Pembuatan Kantong Plastik Ukuran 400 X 550 mm," J. Simetris, P-ISSN: 2252-4983, E-ISSN: 2549-3108 9 (2), pp. 1053-1060.

[3] F. Albaha, 2011, "Proses Pembuatan Rangka Pada Mesin Perajang Daun Pada Mesin Perajang Daun Tembakau Proyek,".

[4] W. Rakhmania and M. Mashuri, 2103 "Pengontrolan kualitas proses produksi rokok sigaret kretek tangan sebuah perusahaan rokok di surabaya menggunakan diagram kontrol multivariat," pp. 1-11.

[5] S. N. Utomo and R. Winarso, 2019, "Rancang Bangun Conveyor Mesin Planer Kayu Dengan," J. Crankshaft, vol. 2, no. 1, pp. 43-48.

[6] Alumnus, 2018, "Design of Automatic Fish," vol. 12, no. 1, pp. 30-35.

[7] S. Jumalli, 2015, "The Modificated of Automatic Feeder for Increasing Effectiveness of Fish Meal in Take,".

[8] D. B. Susilo, H. Wibawanto, and A. Mulwinda,2018, "Prototype Mesin Pengantar Barang Otomatis Menggunakan Load Cell Berbasis Robot Line Follower,” vol. 10, no. 1, pp. 23-29. 